\title{
A NEW LEPANTHES (PLEUROTHALLIDINAE) FROM SOUTHWESTERN COLOMBIA
}

\author{
Luis E. Baquero ${ }^{1,2,7}$, Robinson Galindo-Tarazona ${ }^{3}$, David Haelterman ${ }^{4,5}$ \\ \& AleJANDRo Zuluaga ${ }^{5,6}$
}

\author{
${ }^{1}$ Grupo de Investigación en Biodiversidad, Medio Ambiente y Salud BIOMAS, \\ Carrera de Ingeniería Agroindustrial y Alimentos, Facultad de Ingeniería y Ciencias Agropecuarias, \\ Universidad de Las Américas, Vía a Nayón, Quito 170124, Pichincha, Ecuador \\ ${ }^{2}$ Grupo Científico Calaway Dodson: Investigación y Conservación de Orquídeas del Ecuador, \\ Quito, Ecuador \\ ${ }^{3}$ Dirección Territorial Pacífico, Parques Nacionales Naturales de Colombia, \\ Carrera 117 \# 16B-00, Cali, Colombia \\ ${ }^{4}$ Grupo de Investigación Ecología y Diversidad Vegetal, Universidad del Valle, \\ Calle 13 \# 100-00, Cali, Colombia \\ ${ }^{5}$ Fundación PASS, carrera 100a 17-64, Cali, Valle del Cauca, Colombia \\ ${ }^{6}$ Departamento de Biología, Universidad del Valle, Calle 13 \# 100-00, Cali, Colombia \\ ${ }^{7}$ Author for correspondence: lbaquero@hotmail.com
}

\begin{abstract}
A new species of Lepanthes from southwestern Colombia is presented here. Lepanthes farallonensis belongs to the informal group "manabina", which comprises species with concave and commonly pubescent leaves, flowers resting on the adaxial side of the leaves, and the synsepal with short to long tails. Lepanthes farallonensis is similar to L. smaragdina in the broadly ovate dorsal sepal but differs in the conspicuously twisted upper lobes of the petals, outwardly bent and a depression at the center of the laminae of the lip.
\end{abstract}

RESUmen. Se presenta una nueva especie de Lepanthes del suroeste de Colombia. Lepanthes farallonensis pertenece al grupo informal "manabina", un grupo de especies con hojas cóncavas y comúnmente pubescentes, con flores que descansan sobre el lado adaxial de la hoja y que poseen sinsépalos con caudas que van desde cortas a largas. Lepanthes farallonensis es similar a L. smaragdina en el sépalo dorsal, ampliamente ovado y se diferencia en poseerlos lóbulos superiores de los pétalos conspicuamente retorcidos, doblados hacia afuera y una depresión en la parte media de las láminas del labelo.

Key Words/Palabras clave: Colombian endemic orchids, orquídeas endémicas de Colombia, Farallones de Cali National Natural Park, Parque Nacional Natural Farallones de Cali, Lepanthes smaragdina, Valle del Cauca.

Introduction. Lepanthes Sw., with more than 1100 species, is one of the most diverse genera within the Pleurothallidinae Lindl., only surpassed by Stelis Sw. (Baquero et al. 2018, 2020, Karremans 2019, Karremans \& Vieira-Uribe 2020). The genus is exclusively neotropical, distributed from Mexico to Bolivia as well as the West Indies, but its center of distribution is in the high Andes, especially in Colombia and Ecuador, between 1500 and $3000 \mathrm{~m}$ of elevation in moist forests on mossy twigs or small branches (Luer \& Thoerle 2012). With more than 300 species (Moreno et al. 2020, Vieira-Uribe \& Moreno 2019, Viveros et al.
2015), Colombia is one of the countries with the highest diversity in Lepanthes species, with almost $68 \%$ of these being endemic (Viveros et al. 2015).

Plants of Lepanthes produce stems (ramicauls) enclosed by tubular sheaths named lepanthiform sheaths and bearing a single leaf with a racemose inflorescence. Other characteristics of the genus are the usually transversely lobed petals, and the mid lobe of the lip usually forming a structure called the appendix, the base of the lip adnate to the underside of the footless column, and two hard pollinia (Luer \& Thoerle 2012). Most Lepanthes species exhibit a caespi- 
tose or shortly reptant habit, and the few pollination observations suggest that flowers are pollinated by male fungus gnats which try to copulate with the appendix of the flowers, and by doing so, transporting the pollinia to the stigma of other flowers (Blanco \& Barboza 2005). The fact that most species of Lepanthes flower on the underside of the leaves might be because male's fungus gnats expect to find females under the leaves, but even in species that flower at the adaxial side of the leaves, most present appendix structure beneath the column of their flowers (Blanco \& Barboza 2005, Luer \& Thoerle 2012).

Within the subgenus subgenus Lepanthes sect. Lepanthes subsect. Lepanthes (Luer 1996, Luer \& Thoerle 2012), a group of species distributed in all three Andean ranges of Colombia and both ranges of Ecuador share certain morphological traits and might be related. The species of this informal group, which we here refer to as the "manabina" group (based in Lepanthes manabina Dodson), all have leaves that are concave centrally (deeply to slightly), with slightly to strongly recurved margins, microscopically to conspicuously pubescent adaxial surface, congested inflorescences with flowers resting on the adaxial side of the leaves, provided with shortly to long caudate synsepal and a very small and inconspicuous appendix (Dodson \& Luer 2011, Luer 1996, Luer \& Thoerle 2012) (Fig. 1).

Recently, in a high-elevation forest $(2750 \mathrm{~m}$ of elevation) in the Farallones de Cali National Natural Park, the largest national park in southwest Colombia, a new species of Lepanthes was discovered and is described here.

Materials and methods. Two expeditions were carried out between 2019 and 2020 to the high-elevation forest of the Farallones de Cali National Natural Park, Colombia, where the new species was discovered. The new species was described following the botanical terminology by Lindley (1951). All original descriptions of related species were consulted for detailed comparisons (Luer 1996, Luer \& Thoerle 2012). Flowers were dissected, measured, and photographed using a Celestron Handheld Digital Microscope Pro. Vegetative structures were measured from living plants and reproductive structures from fresh flowers and spirit material.
Lepanthes farallonensis Haelterman, Gal-Tar. \& Zuluaga sp.nov. (Fig. 1A, 2, 3, 4A and C).

TYPE: Colombia. Valle del Cauca: Cali municipality, National Natural Park Farallones de Cali, locality Peñas Blancas, Finca la Cristalina, 2476 m, 2 November 2020, R. Galindo-T \& M. Espitia 1531 (holotype: CUVC 72981).

Diagnosis: Lepanthes farallonensis is similar to Lepanthes smaragdina Luer \& R.Escobar in the general shape of the flower (with broadly ovate sepals) but differs in the darker colored, pubescent leaves which are deeply concave centrally (vs. light green, minutely pubescent and shallowly concave centrally) with the base cuneate ( $v s$. rounded), the lateral sepals longer and narrower with longer tails $(5.2 \times 2.6-3.7$ $\mathrm{mm}$ vs. $4.00 \times 4.30-4.75 \mathrm{~mm}$ wide in L. smaragdina), the petals with the subquadrate upper lobe twisted, outwardly bent, broader than the lower, subfalcate acute lobe ( $v s$. petals with upper lobes oblong, obtuse and the lower lobes triangular, narrowly obtuse in $L$. smaragdina), the lip blades conspicuously depressed in the middle towards the inner margins, oblique in relation to the column axis, oblong with the upper end obtuse and rounded and the lower end acute and rounded vs. the lip blades not depressed, parallel in relation with the column axis, narrowly oblong with the upper and lower ends rounded in L. smaragdina (Fig. 1-4).

Plant medium in size, $9.5-11.0 \mathrm{~cm}$ tall, epiphytic, sympodial, caespitose; roots slender, $0.5-0.7 \mathrm{~mm}$ in diameter. Ramicauls erect or horizontal to pendent, slender, 3.7-9.0 $\mathrm{cm}$ enclosed by 7 to 10 minutely ciliate lepanthiform sheaths with a dilated ostia. Leaf erect, coriaceous, reticulated, juvenile leaves green adaxially and abaxially, glabrous, mature leaves glabrous to pubescent, green abaxially, dark green, suffused with purple adaxially, elliptical-ovate, acute, shortly acuminate, concave and sulcate, the margins revolute, slightly undulated, $3.0-4.5 \mathrm{~cm}$ long, $1.1-1.6 \mathrm{~cm}$ wide, with the base cuneate into a petiole $12.3-15.4 \mathrm{~mm}$ long, the apex mucronate, $1.2-3.1 \mathrm{~mm}$ long. Inflorescence up to 3 , congested, secund, successively many-flowered, up to 9 flowers, up to $19 \mathrm{~mm}$ long including the peduncle, borne on top of the ramicaul, with the flowers above the leaf blade, peduncle 5.4-9.6 $\mathrm{mm}$ long; floral bracts 

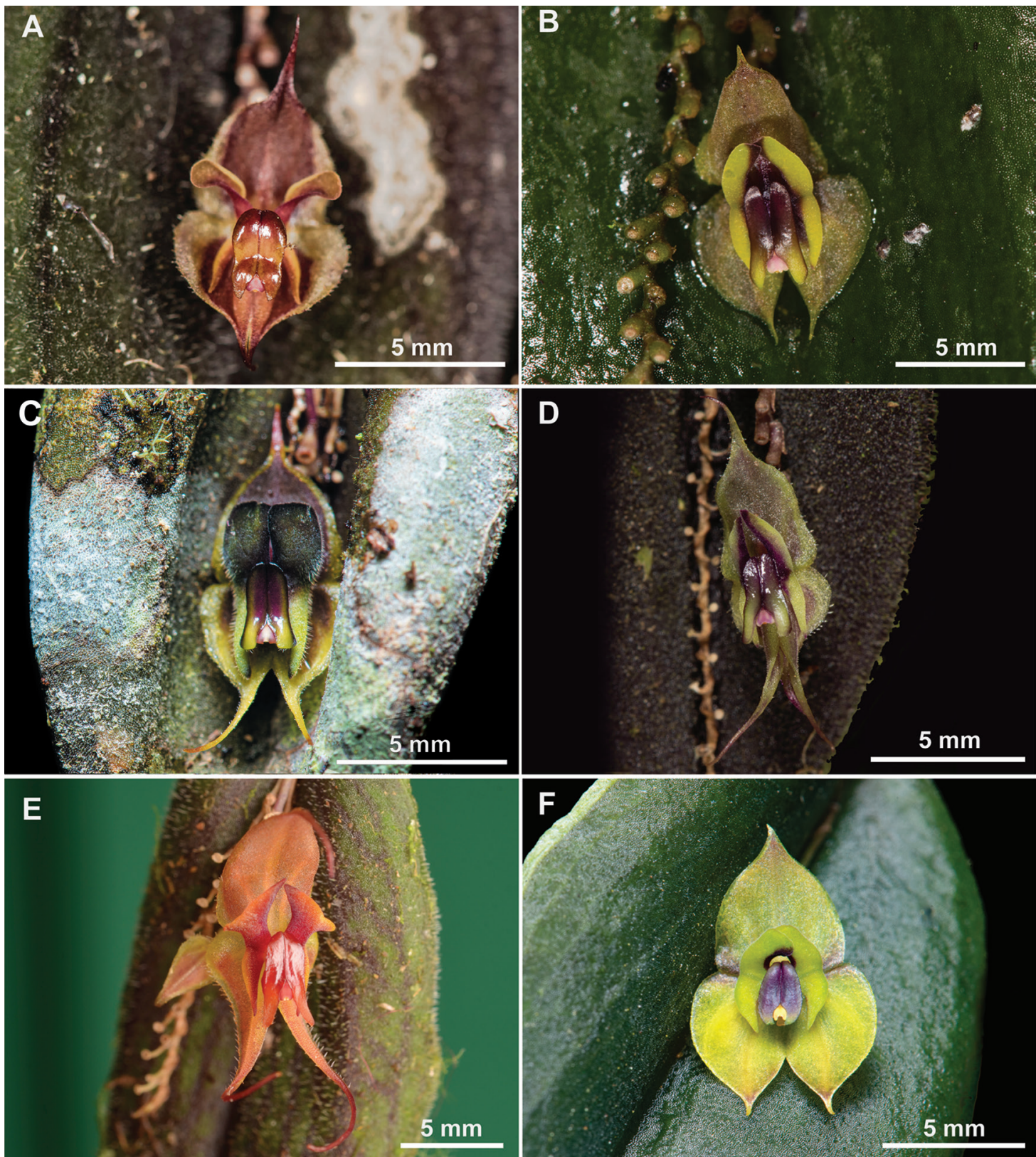

FIGURE 1. Flower comparison within some species in the informal "manabina" group. A. Lepanthes farallonensis, frontal view. B. Lepanthes smaragdina, frontal view. C. Lepanthes manabina, frontal view. D. Lepanthes tomentosa, frontal view. E. the Ecuadorian Lepanthes dactylopetala, frontal view. F. Lepanthes ortiziana, frontal view. Photos by Robinson Galindo-Tarazona (A, B, D), Sebastián Moreno (C, F), Luis E. Baquero (E).

minutely scabrous $0.9-1.5 \mathrm{~mm}$ long; pedicels $1.1-1.4$ $\mathrm{mm}$ long. Ovary 3-costate, 3.2-3.5 mm long. Sepals rufous to liver-colored with ochroleucous margins and purple caudae, minutely pubescent within, carinate, margins with filiform papillae, the dorsal sepal widely ovate, acuminate, caudate, $5.2 \mathrm{~mm}$ long, $3.7 \mathrm{~mm}$ wide, 3-veined, connate to the lateral sepals for $2.6 \mathrm{~mm}$, the lateral sepals broadly ovate, oblique, caudate, $5.2 \mathrm{~mm}$ long, connate $2.6 \mathrm{~mm}$ into a widely ovate synsepal, 2.3 $\mathrm{mm}$ wide together, each 2 -veined, caudate, with over- 
lapping caudae, $1.8 \mathrm{~mm}$ long. Petals yellow suffused with carmine, dark ochre color at the margin of the upper lobes, velvety, transversally bilobed, $0.3-0.9 \mathrm{~mm}$ long, $3.9 \mathrm{~mm}$ wide, the upper lobe subquadrate, twisted at the apex, outwardly bent, much broader than the lower lobe, the lower lobe sub-falcate, acute. Lip redbrown, the blades glabrous and shiny, oblique in relation to the column axis, bilaminate, $2.0-2.2 \mathrm{~mm}$ long, $0.5-0.8 \mathrm{~mm}$ wide, the blades conspicuously depressed in the middle towards the inner margins, oblong with the upper ends obtuse and rounded and the lower ends acute and rounded, the connectives short cuneate, narrow body, connate to the column, the appendix short broadly triangular, minutely trilobate. Column $1.9 \mathrm{~mm}$ long with the anther dorsal and the stigma ventral. Anther cap $0.6 \mathrm{~mm}$ wide. Pollinia $0.3 \mathrm{~mm}$ long.

Toponymy: Lepanthes farallonensis is named after the Farallones de Cali National Natural Park, where this species was discovered.

Habitat And ECology: Lepanthes farallonensis is endemic in the Valle del Cauca Department, growing in Andean cloud forest around $2750 \mathrm{~m}$ of elevation in the Farallones de Cali National Natural Park. This Park is the largest protected area in southwestern Colombia, with 196,430 ha, and a largely understudied and high biodiversity region with many new orchid species. It grows sympatrically with many other Pleurothallidinae orchids such as Barbosella prorepens (Rchb.f.) Schltr., Brachionidium sp., Lepanthes speciosa Luer \& Hirtz, Lepanthes tomentosa Luer, Masdevallia platyglossa Rchb.f., Platystele pamelae Baquero \& Zuchan, Pleurothallis spp., Scaphosepalum swertifolium (Rchb.f.) Rolfe, Stelis spp., as well as orchid species from other subtribes such as Maxillaria (M. cf. embreei Dodson, M. platyloba Schltr.,) and Epidendrum (E. aurimurinus Hágsater, E.Santiago \& Gal.-Tar, E. cylindraceum Lindl.) (Fig. 5).

Phenology: Lepanthes farallonensis has been observed flowering in December in its native habitat, although it probably flowers all year round. The plants have successive inflorescences, which last for approximately two months each. That produce up to nine successive flowers, each ramicaul can produce up to three inflorescences.
Discussion. The Farallones de Cali region is particularly rich in species of Lepanthes of the informal "manabina" group, with eight different species growing in the area (L. farallonensis, L. dodsonii Luer, L. foreroi P.Ortiz, O.Pérez \& E.Parra, L. ortiziana O.Pérez, E.Parra \& Kolan., L. manabina Dodson, $L$. smaragdina Luer \& R.Escobar, Lepanthes sp.nov. and L. tomentosa Luer, as well as a ninth species, L. cincinnata Luer \& R.Escobar which grows further north in the same department (Valle del Cauca). Considering the number of species of Lepanthes belonging to this group, this area could be the center of radiation of these closely related species (Fig. 1).

Some of them, such as Lepanthes manabina, extend their distribution towards the northern departments in the Western Andes of Colombia and southern departments of the same mountain range, ending their distribution in the Western Andes of northern Ecuador. In addition, at least two species extend their distribution range to other mountain ranges in Colombia, L. manabina is known to occur in the Central Andes, and L. tomentosa is also found in the Central and Eastern Andes.

The shape of the petals of Lepanthes farallonensis is one of the main characters that easily distinguish this species from any other species of the "manabina group", the lower lobe being much narrower than the twisted upper lobe, resulting in the backside of the petals visible at their upper apical portion instead of showing their frontside as in most other known Lepanthes species (Fig. 2-4). Although an incurved process of the stigma has been observed and mentioned in the original description of L. ortiziana O.Pérez, E.Parra \& Kolan. which belongs to the "manabina group" this was not observed in L. farallonensis. Although other species of Lepanthes like L. elephantina Luer \& R.Escobar, $L$. medusae Luer \& R. Escobar, and L. tatamae S.VieiraUribe \& J.S.Moreno have upper lobes of the petals bent facing downwards, reminiscent of the petals of $L$ farallonensis, none of them have twisted lobes, outwardly bent of the petals and flowers resting adaxially on the leaf. In addition, the lip of L. farallonensis is like the lip of Lepanthes smaragdina. However, the lip blades are conspicuously depressed in the middle towards the inner margins compared to the flat lip blades in all their extension in $L$. smaragdina. Also, the appendix of $L$. farallonensis is broadly triangular, while the appendix of L. smaragdina is triangular (Fig. 2-4). 


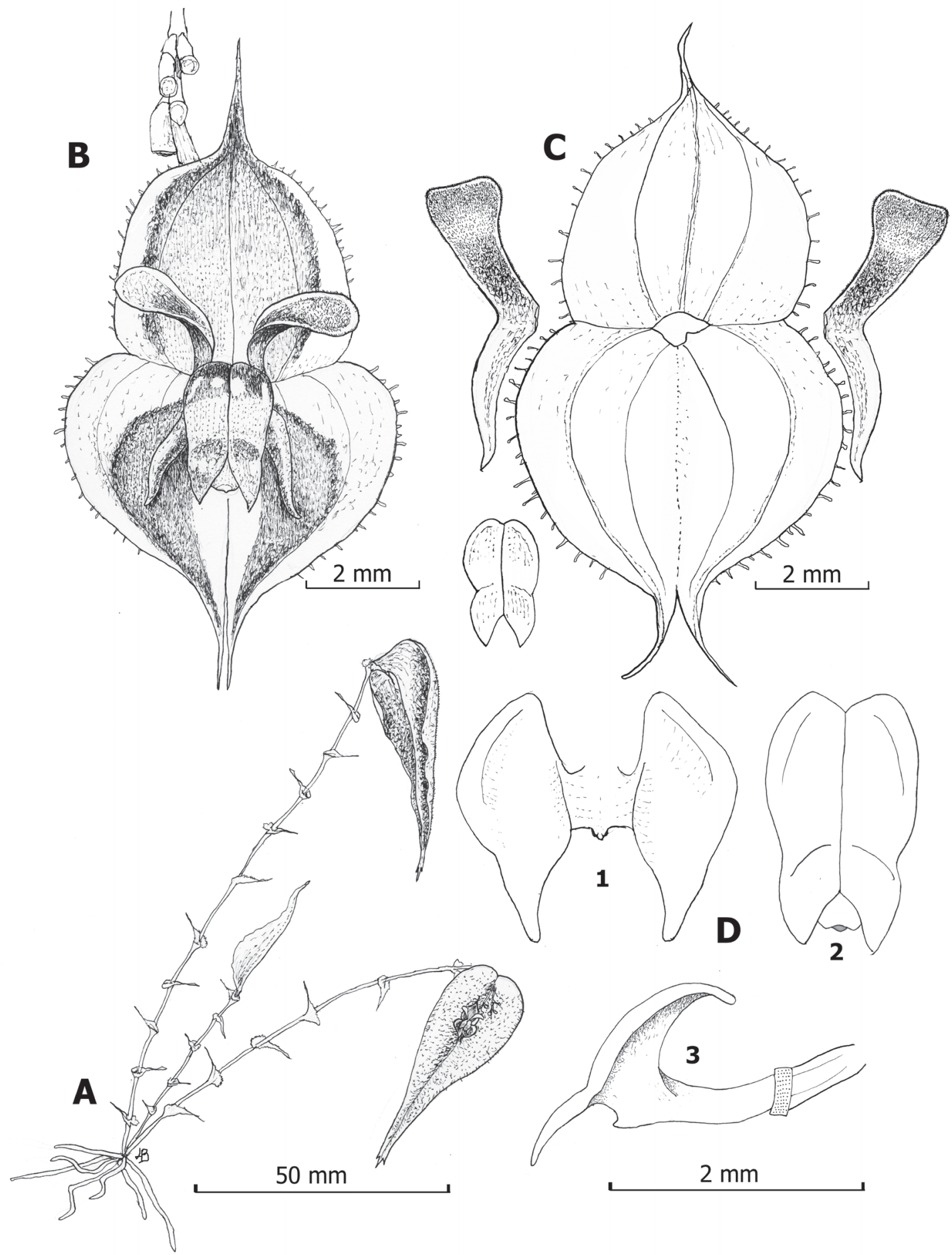

FIgURE 2. Illustration of Lepanthes farallonensis Haelterman, Gal-Tar. \& Zuluaga. A. Habit. B. Flower. C. Dissected perianth. D1. Lip in expanded position, adaxial view. D2. Adaxial view of normal position of the lip. D3. Later view of the ovary, column and lip. Drawing by Luis E. Baquero from the holotype. 

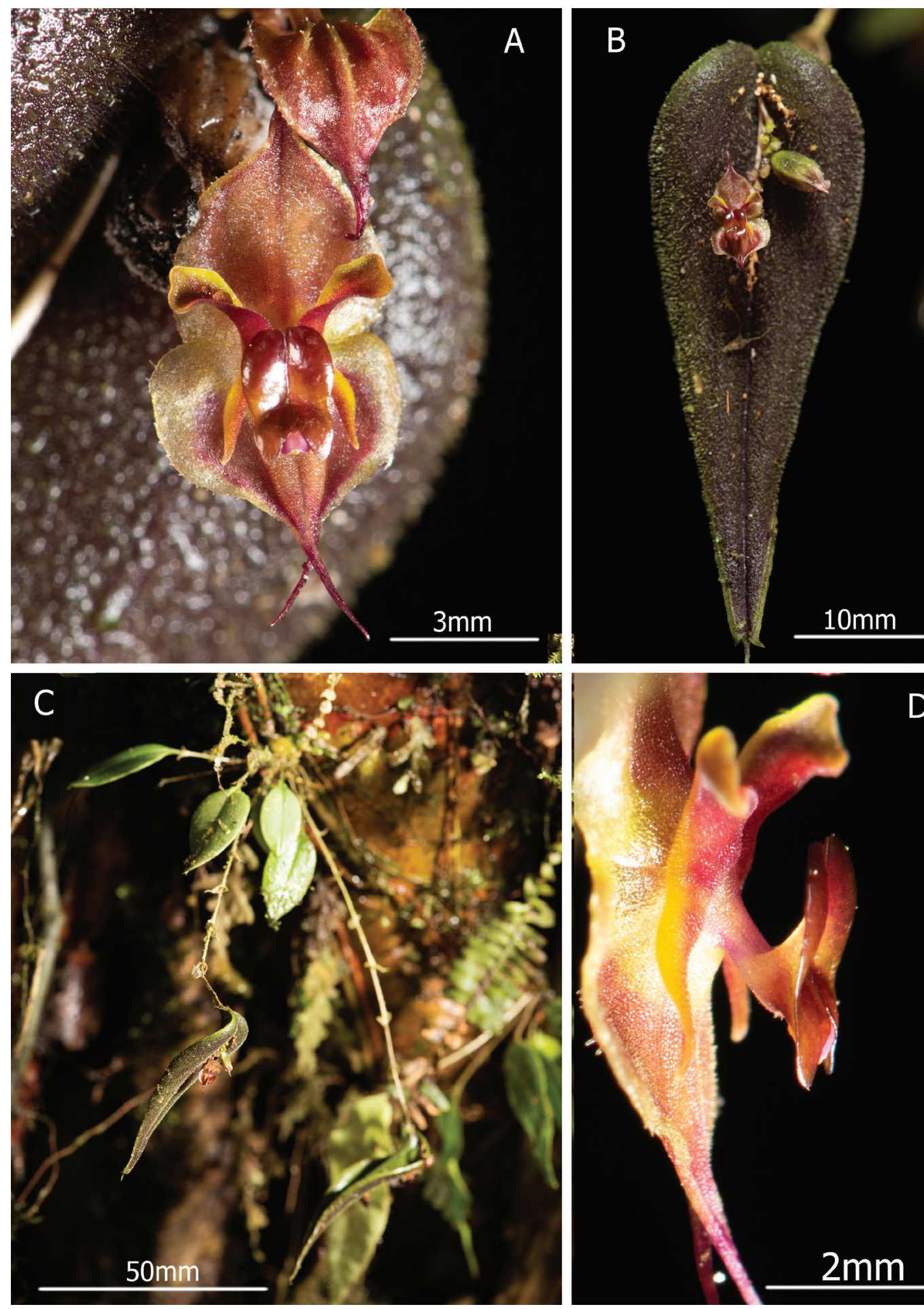

Figure 3. Lepanthes farallonensis Haelterman, Gal-Tar. \& Zuluaga. A. Frontal view of the flower in situ. B. Leaf and flower in situ. C. Plant in situ. D. Lateral view of the lip and petals. Photos taken in situ by Robinson Galindo-Tarazona. 

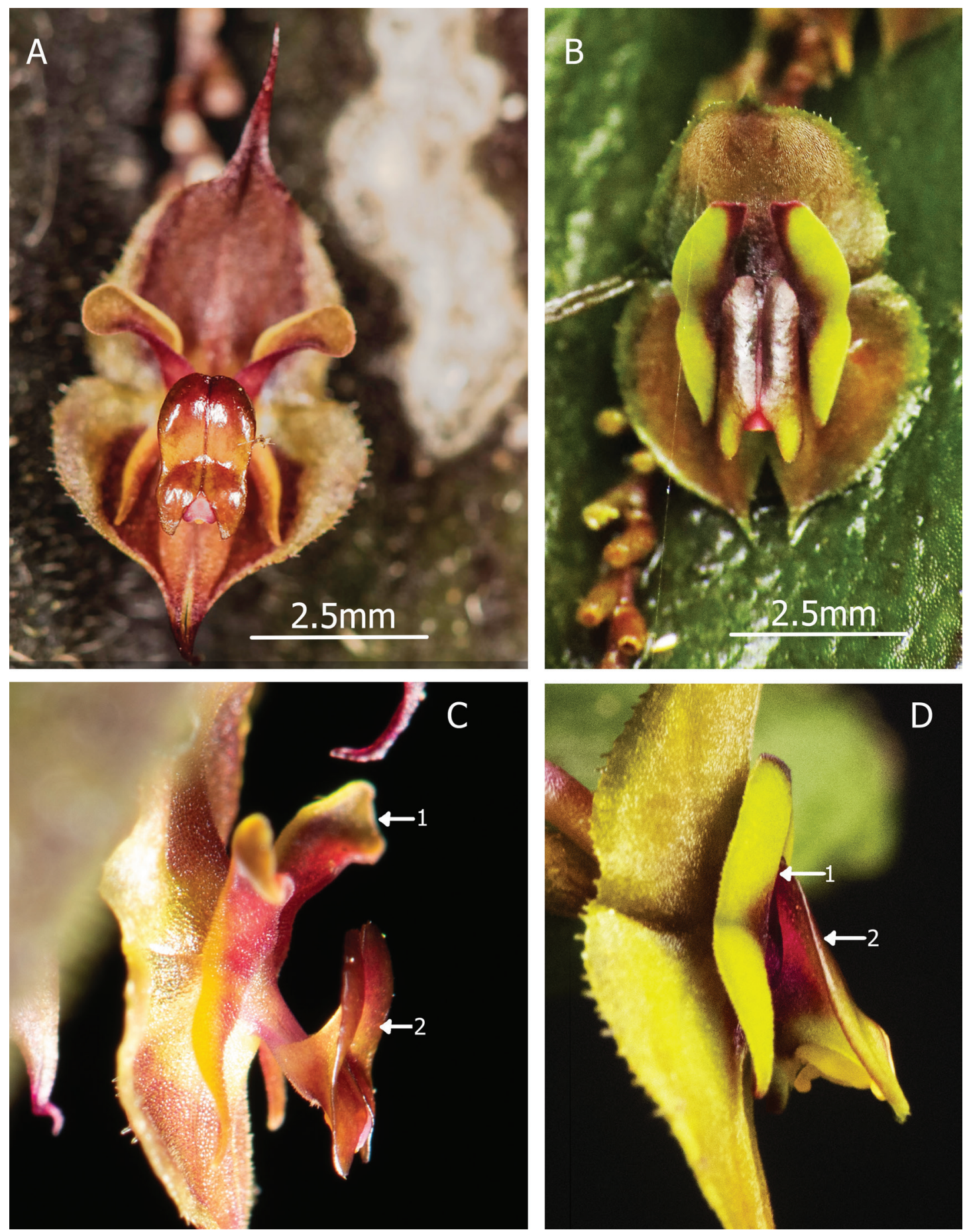

FIgURE 4. Comparison between Lepanthes farallonensis Haelterman, Gal-Tar. \& Zuluaga and Lepanthes smaragdina. A. Frontal view of the flower of $L$. farallonensis. B. Frontal view of the flower of L. smaragdina. C. Lateral view of the flower of L. farallonensis: C1. Petal, C2. Lip. D. Lateral view of the flower of L. smaragdina: D1. Petal, D2. Lip. Photos taken in situ by Robinson Galindo-Tarazona. 


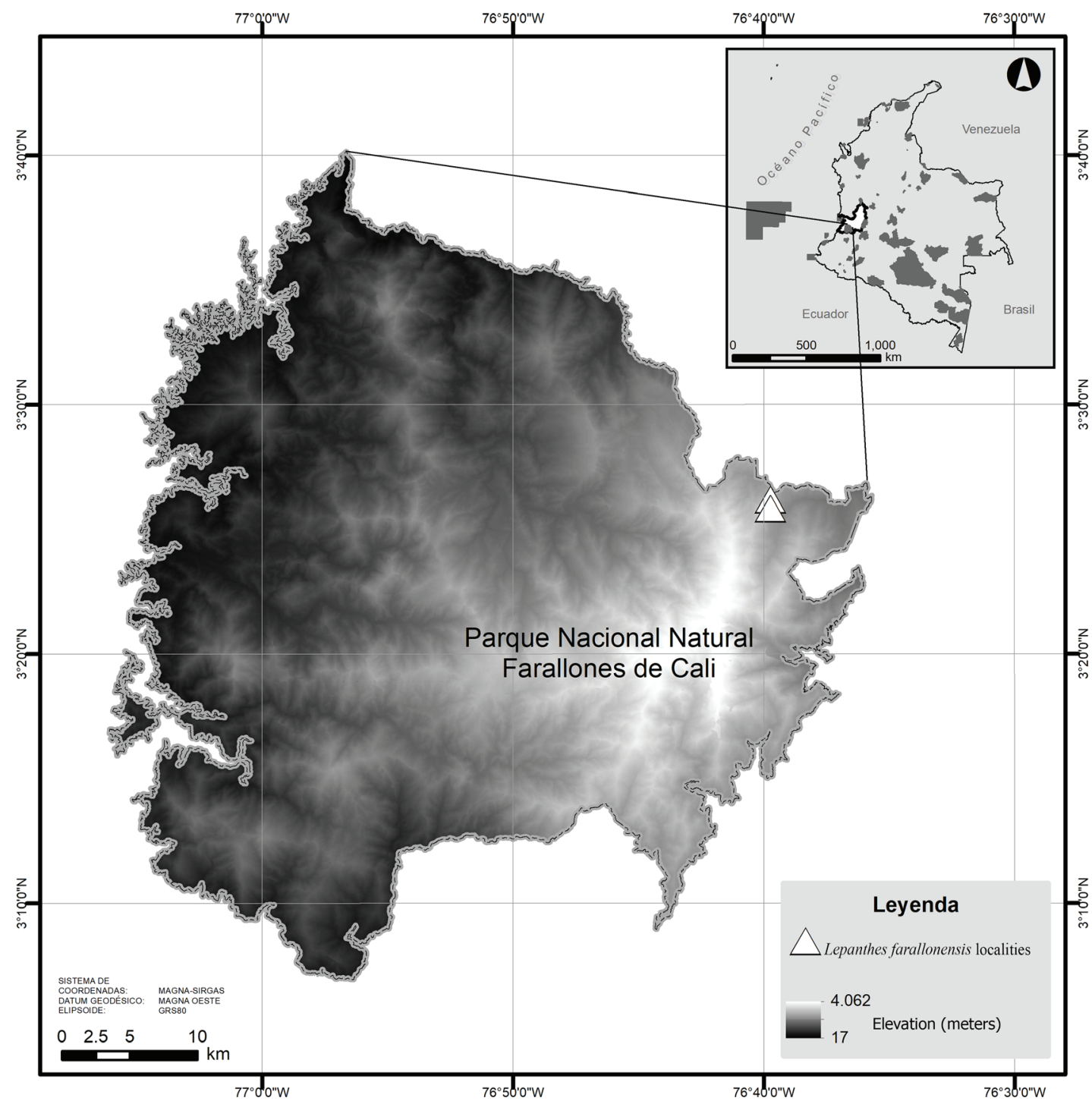

FIgURE 5. Distribution map of Lepanthes farallonensis Haelterman, Gal-Tar., \& Zuluaga. Prepared by Robinson Galindo.

Conservation status: The only known population grows within the largest protected area from southwestern Colombia, The Farallones de Cali National Natural Park. So, it might be preserved from deforestation for a long time, and hopefully from illegal poaching. Nevertheless, climate change is a concern because moisture tends to disappear from lower areas and is pushed to higher elevations due to increasing temperatures. Therefore, climate change can cause a new threat to miniature orchid species such as L. farallonensis, which are highly sensitive to low humidity and heat excess.
AcKNowledgments. We thank CELSIA for funding part of this research in the Farallones de Cali National Natural Park. To Farallones de Cali National Park for the collection permits extended to Robinson Galindo as a public authority of the National Park. We also thank Universidad de Las Américas (UDLA) for funding research of Luis E. Baquero R. To the Grupo Conserva Foundation for their logistical support and National Natural Parks of Colombia, especially Claudia Acevedo and Martha Espitia from the Farallones de Cali National Natural Park. Finally, we especially thank Melisa Alegria for her help with the measurements of the plant, Emmanuel Zapata for preparing the map of the species, and Sebastian Moreno for the pictures of L. manabina and L.ortiziana. 


\section{LITERATURE CITED}

Baquero, L. E., Moreno, J. S. \& Iturralde, G. A. (2018). The Four Footed Lepanthes (Pleurothallidinae), a new species from north-western Ecuador. Lankesteriana, 18(3), 183-188.

Baquero, L. E., Donoso T., J. J. \& Jiménez, M. M. (2020). A new gold-colored Lepanthes (Pleurothallidinae: Orchidaceae) from Southeast Ecuador. Lankesteriana, 20(2), 257-262.

Blanco, M. A. \& Barboza, G. (2005). Pseudocopulatory pollination in Lepanthes (Orchidaceae: Pleurothallidinae) by fungus gnats. Annals of Botany, 95(5), 764-772.

Dodson, C.H. \& Luer, C.A. (2011). Orchidaceae, part 7. Lepanthes and affiliates. In: C. Persson \& B. Ståhl (eds), Flora of Ecuador 88. Department of Plant and Environmental Sciences, University of Gothenburg, Göteborg, Sweden.

Karremans, A. P. (2019). To be, or not to be a Stelis. Lankesteriana, 19(3), 281-343.

Karremans, A. P \& Vieira-Uribe, S. (2020). Pleurothallids Neotropical Jewels (pp. 1, 2). Quito: Imprenta Mariscal.

Lindley, J. (1951). Glosología o de los Términos usados en botánica. Universidad Nacional, Tucuman.

Luer, C. A. (1996). Icones Pleurothallidinarum. XIV. The genus Lepanthes subgenus Lepanthes in Ecuador (Orchidaceae). Monographs in Systematic Botany from the Missouri Botanical Garden, 61(3), 1-255.

Luer, C. A. \& Thoerle, L. (2012). Icones Pleurothallidinarum XXXII. Lepanthes of Colombia (Orchidaceae). Monographs in Systematic Botany from the Missouri Botanical Garden, 123, 1-296.

Moreno, J. S., Pisso-Florez, G. A. \& Vieira-Uribe, S. (2020). Discoveries in indigenous territories: two new species of Lepanthes (Orchidaceae: Pleurothallidinae) in southwestern Colombia. Lankesteriana, 20(2), 229-239.

Vieira-Uribe, S. \& Moreno, J. S. (2019). Three new Lepanthes (Orchidaceae: Pleurothallidinae) from the Alto de Ventanas ecoregion in Antioquia, Colombia. Lankesteriana, 19(2), 63-75.

Viveros, P., Luer, C.A. \& Celis, M. (2015). Lepanthes. En: R. Bernal, S. R. Gradstein \& M. Celis (Eds), Catálogo de plantas y líquenes de Colombia. Instituto de Ciencias Naturales, Universidad Nacional de Colombia, Bogotá. Retrieved from http://catalogoplantasdecolombia.unal.edu.co/es/resultados/genero/Lepanthes/ [Accesed November 23, 2021] 
LANKESTERIANA 